\title{
Sequence variability of the pattern recognition receptor Mermaid mediates specificity of marine nematode symbioses
}

\author{
Silvia Bulgheresi ${ }^{1,4}$, Harald R Gruber-Vodicka ${ }^{2,4}$, Niels R Heindl ${ }^{1}$, Ulrich Dirks ${ }^{2}$, \\ Maria Kostadinova ${ }^{3}$, Heimo Breiteneder ${ }^{3}$ and Joerg A Ott ${ }^{2}$ \\ ${ }^{1}$ Department of Genetics in Ecology, University of Vienna, Althanstrasse 14, 1090 Vienna, Austria; \\ ${ }^{2}$ Department of Marine Biology, University of Vienna, Althanstrasse 14, 1090 Vienna, Austria and ${ }^{3}$ Center for \\ Physiology, Pathophysiology and Immunology, Medical University of Vienna, Währinger Gürtel 18-20, 1090 \\ Vienna, Austria
}

\begin{abstract}
Selection of a specific microbial partner by the host is an all-important process. It guarantees the persistence of highly specific symbioses throughout host generations. The cuticle of the marine nematode Laxus oneistus is covered by a single phylotype of sulfur-oxidizing bacteria. They are embedded in a layer of host-secreted mucus containing the mannose-binding protein Mermaid. This $\mathrm{Ca}^{2+}$-dependent lectin mediates symbiont aggregation and attachment to the nematode. Here, we show that Stilbonema majum-a symbiotic nematode co-occurring with $L$. oneistus in shallow water sediment-is covered by bacteria phylogenetically distinct to those covering $L$. oneistus. Mermaid cDNA analysis revealed extensive protein sequence variability in both the nematode species. We expressed three recombinant Mermaid isoforms, which based on the structural predictions display the most different carbohydrate recognition domains (CRDs). We show that the three CRDs (DNT, DDA and GDA types) possess different affinities for $L$. oneistus and S. majum symbionts. In particular, the GDA type, exclusively expressed by $S$. majum, displays highest agglutination activity towards its symbionts and lowest towards its $L$. oneistus symbionts. Moreover, incubation of $L$. oneistus in the GDA type does not result in complete symbiont detachment, whereas incubation in the other types does. This indicates that the presence of particular Mermaid isoforms on the nematode surface has a role in the attachment of specific symbionts. This is the first report of the functional role of sequence variability in a microbeassociated molecular patterns receptor in a beneficial association.
\end{abstract}

The ISME Journal (2011) 5, 986-998; doi:10.1038/ismej.2010.198; published online 13 January 2011

Subject Category: microbe-microbe and microbe-host interactions

Keywords: symbiosis; C-type lectin; sulfur-oxidizing bacteria; nematode; microbe-associated molecular pattern receptor; marine sediment

\section{Introduction}

A high degree of specificity has been experimentally demonstrated for a number of microbial symbioses. The degree of taxonomic specificity (that is, genus, species and strain) varies among the associations, and certain host species within one genus may display stricter symbiont selectivity than others (Chaston and Goodrich-Blair, 2010). In the case of thiotrophic marine nematodes-Stilbonematinae, Chromadoria (Ott et al., 2004a,b)—the bacteria

Correspondence: S Bulgheresi, Department of Marine Biology, University of Vienna, Althanstrasse 14, Vienna 1090, Austria.

E-mail: silvia.bulgheresi@univie.ac.at

Contribution 894 from the Carrie Bow Cay Laboratory, Caribbean Coral Reef Ecosystem Program, NMNH, Washington, DC.

${ }^{4}$ These authors contributed equally to this work.

Received 26 July 2010; revised 18 November 2010; accepted 21 November 2010; published online 13 January 2011 associated with Laxus oneistus (Polz et al., 1994), Eubostrichus dianae (Polz et al., 1999) and three Robbea species (Bayer et al., 2009) have been molecularly characterized so far. Except for $E$. dianae, all these stilbonematids are covered by a microbial coat composed of a single phylotype of Gammaproteobacteria. Symbionts not only appear to be a major component of the diet of the stilbonematids, but may also protect their hosts against sulfide poisoning (Ott et al., 1991; Hentschel et al., 1999). Although in this small sub-family of nematodes, a high degree of specificity seems to be the rule, we still know little about the molecular mechanisms underlying the selection of cooperative microbes and the exclusion of potential cheating or nonperforming ones. As pointed out by Chaston and Goodrich-Blair (2010), specificity may be mediated either by (1) minor variations in molecules conserved among phylogenetically related symbiotic 
partners, or (2) by the presence or absence of genetic determinants of host-range specificity in a given symbiotic partner. A good molecular candidate for mediating stilbonematid symbiosis specificity is Mermaid (Bulgheresi et al., 2006), a secreted $\mathrm{Ca}^{2+}$ dependent sugar-binding protein (C-type lectin). Lectins are proteins that have at least one noncatalytic domain that reversibly and non-enzymatically binds specific mono- or oligosaccharides (carbohydrate recognition domain (CRD); (Peumans and Van Damme, 1995; De Hoff et al., 2009). They are found in cells, membranes and secretomes of plants, animals and bacteria. The degree of sequence variation the lectins tolerate in their ligand-binding pocket is remarkable and comparable to that of immunoglobulins (McMahon et al., 2005). This sequence variation mirrors carbohydrate variability, which itself arises by differences in (1) carbon backbone length of the monomer, (2) anomericity, (3) side-group orientation, (4) substitution and (5) branching. As a result, cells exposing a characteristic carbohydrate repertoire can be recognized by specific lectins. Like most lectins, Mermaid appears to be multivalent and may therefore clump cells together. The mature protein is composed of one CRD, structurally and functionally similar to the human dendritic cell-specific immunoreceptor dendritic cell-specific ICAM-3 grabbing non-integrin; (DC-SIGN) (Bulgheresi et al., 2006; Zhang et al., 2006, 2008; Nabatov et al., 2008; Mittal et al., 2009). Mermaid is expressed and secreted from subcuticular glandular sense organs (Nebelsick et al., 1992) onto the cuticle of $L$. oneistus. Only the posterior glandular sense organs underlying the bacterial coat secrete this lectin, whereas it is absent from the anterior part of cuticle to which no symbionts are attached. Moreover, a recombinant form of Mermaid aggregated the symbionts and competed with native Mermaid for symbiont attachment (Bulgheresi et al., 2006). All these data point to a pivotal role of Mermaid in L. oneistus-symbiont attachment. As for the bacterial symbiont, it is predicted to utilize surface-exposed mannose residues to bind to the host lectin (Nussbaumer et al., 2004), consistently with the ability of recombinant Mermaid to bind mannotriose in glycan specificity assays (Nabatov et al., 2008). Moreover, recombinant Mermaid may bind to the core lipopolysaccharide (LPS) of a rough Escherichia coli strain (Zhang et al., 2006), and inhibits the interaction of Yersinia pestis core LPS with dendritic cell-specific immunoreceptor (Zhang et al., 2008).

Mermaid genes are also expressed by Stilbonema majum, another stilbonematid nematode, thriving in the same microhabitat as L. oneistus. Whereas the latter carries a monolayer of $2.1 \times 0.6 \mu \mathrm{m}$ rods, the former bears up to 10 layers of $1.3 \times 0.6 \mu \mathrm{m}$ oval bacteria. Because of the different symbiont morphology and coat architecture, the two co-occurring nematodes were long hypothesized to carry distinct symbiont phylotypes. Moreover, they were found to express two and three Mermaid isoforms, respectively. These differed at three amino acid positions (105, 108 and 109). On the basis of a threedimensional model of Mermaid CRD, these substitutions were speculated not to dramatically affect the protein conformation (Bulgheresi et al., 2006).

The hypothesis behind the present work is that minor variations in the protein sequence of their CRD might mediate attachment of specific symbionts to the nematode cuticle. We first assessed the phylogenetic position of the $S$. majum symbiont to confirm that it differs from that of the $L$. oneistus symbiont. Subsequently, we assessed the degree of both $L$. oneistus and $S$. majum Mermaid sequence variability by screening Mermaid cDNA libraries obtained from each species to saturation. We then selected three Mermaid isoforms which, based on structural predictions, were expected to bear the most different CRDs. Finally, we expressed recombinant forms thereof and tested whether their binding activity towards different symbionts would significantly differ.

\section{Materials and methods}

\section{Nematode collection}

L. oneistus and S. majum were collected in March 2009 in $\sim 1 \mathrm{~m}$ depth from a shallow water back-reef sandbar, off Carrie Bow Cay, Belize $\left(16^{\circ} 48^{\prime} 11 \mathrm{~N}\right.$, $\left.88^{\circ} 04^{\prime} 55 \mathrm{~W}\right)$. The worms were extracted from the sand by shaking it in seawater and pouring the supernatant through a $63-\mu \mathrm{m}$-pore-size mesh screen. Single individuals were then picked by hand under a dissecting microscope. For DNA extraction and fluorescence in situ hybridization (FISH), worms were fixed in methanol. For mRNA extraction, batches of freshly collected nematodes were flash frozen in liquid nitrogen. All samples were deep frozen for transportation and storage, except for the live $L$. oneistus nematodes used in the in vivo dissociation experiments. In the case of $S$. majum, their identity was confirmed by direct sequencing of an $18 \mathrm{~S}$ rRNA gene fragment (data not shown).

\section{Symbionts collection}

Batches of 500 and 150 freshly collected L. oneistus and $S$. majum, respectively, were incubated for $3 \mathrm{~min}$ in an $\mathrm{MgSO}_{4}$ solution, isotonic to seawater, to induce symbiont dissociation. Dissociated symbionts were collected by 2 min centrifugation at 6Kr.p.m. Symbiont pellets were washed three times in filtered seawater and deep frozen for transport and storage.

DNA extraction, PCR amplification and cloning of the S. majum $18 S$ rRNA gene and of the S. majum symbiont $16 S$ rRNA gene

DNA was extracted from three separate $S$. majum individuals as described (Schizas et al., 1997), and 
$2 \mu \mathrm{l}$ of each extraction were used as PCR template. A 1720 nt-long fragment of the 18S rRNA gene was amplified for each $S$. majum worm by PCR with the general eukaryotic primers if (5'-CTGGTTGAT YCTGCCAGT-3') and 2023r (5'-GGTTCACCTACGG AAACC-3') (Pradillon et al., 2007). Cycling conditions were as follows: $94{ }^{\circ} \mathrm{C}$ for $4 \mathrm{~min}$ followed by 35 cycles of $94{ }^{\circ} \mathrm{C}$ for $45 \mathrm{~s}, 49^{\circ} \mathrm{C}$ for $30 \mathrm{~s}, 72^{\circ} \mathrm{C}$ for $1 \mathrm{~min}$ and a final elongation step of $72{ }^{\circ} \mathrm{C}$ for $10 \mathrm{~min}$. The PCR products obtained from the three $S$. majum individuals were purified using the MinElute PCR purification kit (Qiagen, Hilden, Germany) and directly sequenced with the PCR primers.

A 1499-nt long fragment of the 16S rRNA gene was amplified for each $S$. majum worm by PCR with bacterial primers $616 \mathrm{~V}$ (5'-AGAGTTTGATYMTGGC TC-3'; Juretschko et al., 1998) and 1492R (5'-GGYTA CCTTGTTACGACTT-3'; Kane et al., 1993). Cycling conditions were as follows: $94^{\circ} \mathrm{C}$ for $5 \mathrm{~min}$, followed by 35 cycles of $94{ }^{\circ} \mathrm{C}$ for $45 \mathrm{~s}, 47^{\circ} \mathrm{C}$ for $45 \mathrm{~s}, 72^{\circ} \mathrm{C}$ for $1 \mathrm{~min} 30 \mathrm{~s}$ and a final elongation step of $72^{\circ} \mathrm{C}$ for $10 \mathrm{~min}$. PCR products were gel purified and cloned into pCR2.1-TOPO using the TOPO TA Cloning Kit (Invitrogen Life Technologies, Darmstadt, Germany). We randomly picked and fully sequenced eight, seven and six clones from each of the three 16S rRNA gene libraries obtained from the three $S$. majum individuals. Sequences were aligned and compared with CodonCode Aligner 1.6.3 software (CodonCode Corporation, Dedham, MA, USA).

$16 S$ rRNA gene-based phylogenetic analysis

A bacterial 16S rRNA gene data set was compiled adding closely related sequences from the GenBank using BLASTN (Altschul et al., 1990). The data set was aligned using MAFFT G-INS-I (Katoh et al., 2005). We used Bayesian inference- (MrBayes; Ronquist and Huelsenbeck, 2003), maximum likelihood- (RAxML; Stamatakis, 2006), parsimony- and distance-based algorithms to reconstruct the phylogenetic position of the symbiont. Node stability was evaluated using posterior probabilities (Bayesian inference) and bootstrapping (all other algorithms). Sequences of Alkalimnicola halodurans (AJ404972) and Nitrococcus mobilis (L35510) served as out-groups.

Fluorescence in situ hybridization

We designed a FISH probe (Sms444) specific to the S. majum ectosymbiont 16SrRNA gene (GenBank accession number HM776017) by using the ARB PROBE_DESIGN tool (arb software package Ludwig et al., 2004; Table 1), and confirmed its specificity by comparing it with all available sequences in GenBank, SILVA and Greengenes using probeCheck (Loy et al., 2008). The sequence most similar to Sms444, found in these databases, has a weighted mismatch of 2.6 and corresponds to a fragment of the 16S rRNA gene of the Robbea sp. 3 ectosymbiont (EU711428). Accordingly, an unlabeled competitor 
probe (Rhs444) was designed (Eurofins MWG Operon, Ebersberg, Germany). All other probes used were fluorescently labeled on their $5^{\prime}$ end (Thermo Fisher Scientific, Ulm, Germany). FISH was performed according to Manz et al., 1992. To determine stringent hybridization conditions, a formamide series was conducted for all the probes $(0 \%, 10 \%$, $15 \%, 20 \%, 25 \%, 30 \%, 35 \%, 40 \%, 45 \%, 55 \%$ and $70 \%)$. Fixed $S$. majum nematodes were incubated at $46{ }^{\circ} \mathrm{C}$ in hybridization buffer containing the optimal formamide concentration and respective probes (0.46 M NaCl, $20 \mathrm{mM}$ TrisHCl (pH 8.0) and $0.001 \%$ sodium dodecyl sulfate; refer to Table 1 for optimal incubation time, formamide percentage and probe concentrations). Hybridization was stopped by incubation in washing buffer $(70 \mathrm{mM} \mathrm{NaCl}, 20 \mathrm{mM}$ Tris $\mathrm{HCl}(\mathrm{pH}$ 8.0) and $0.125 \mathrm{M}$ EDTA) for $15 \mathrm{~min}$ at $48{ }^{\circ} \mathrm{C}$ and subsequently in ice-cold $\mathrm{dd}_{2} \mathrm{O}$ for 3 sec. Nematodes were dried quickly under compressed air, mounted in DAPI Vectashield (Vector Labs, Burlingame, CA, USA) and examined using a Leica TCS-SP2 confocal laser-scanning microscope combined to an inverted DM-IRE2 microscope (Leica Microsystems, Heidelberg, Germany).

Mermaid $c D N A$ libraries

L. oneistus and S. majum mRNA were extracted with the QuickPrep Micro mRNA Purification Kit (Amersham Biosciences, Freiburg, Germany) from deep-frozen batches of 500 individuals each, and cDNA was synthesized with the Ready-To-Go T-primed first-strand kit (Amersham Biosciences). Full-length Mermaid cDNA libraries of $L$. oneistus and $S$. majum were obtained using primer SB34 binding the $5^{\prime}$-untranslated region $\left(5^{\prime}\right.$-TTTTTTATT TCACAGCCATCGGTTTCC- $3^{\prime}$ ) and primer SB27 binding the $3^{\prime}$-untranslated region (5'-CTAACAGTC ACTGACTCTCAACGAATCC- $3^{\prime}$ ). Cycling conditions were as described (Bulgheresi et al., 2006). Full-length Mermaid cDNA from both L. oneistus and $S$. majum was gel purified and cloned into pCR2.1-TOPO using the TOPO TA Cloning Kit (Invitrogen Life Technologies). We randomly picked and fully sequenced $89 \mathrm{~L}$. oneistus and 113 $S$. majum cDNA clones.

\section{Immunofluorescence}

A custom-made rabbit polyclonal antibody was raised against a synthetic peptide corresponding to Mermaid amino acids 65-81 (Genosphere Biotechnologies, Paris, France). Antibody specificity was tested and immunostaining performed as described (Bulgheresi et al., 2006). In brief, methanol-fixed S. majum individuals were rehydrated and washed in phosphate-buffered saline containing $0.1 \%$ Tween-20 (washing solution). Blocking was carried out for $1 \mathrm{~h}$ in washing solution containing $2 \%$ (wt/vol) bovine serum albumin (blocking solution). Worms were incubated overnight under gentle agitation at $4{ }^{\circ} \mathrm{C}$ in blocking solution containing peptide antibody anti-Mermaid or rabbit preimmune serum as the negative control (1:500 dilution each). Unbound primary antibody was removed by three washing steps in washing solution and Alexa488conjugated secondary anti-rabbit antibody (Molecular Probes, Eugene, OR, USA) was then applied at a 1:500 dilution in blocking solution for $1 \mathrm{~h}$ at room temperature. After three washing steps, worms were mounted in the Slow-Fade Antifade kit (Molecular Probes). Images were recorded on a laser-scanning confocal microscope (described above).

Mermaid isoforms sequence alignment and analysis The sequences of each worm were translated, aligned and compared using the software package Geneious (Biomatters, Auckland, New Zealand; Drummond et al., 2009). Only isoforms encoded by at least two clones were aligned to eliminate random sequencing errors as a source of variation. Secondary structure predictions were carried out by using the NetSurfP tool available online at http://www. cbs.dtu.dk/services (Petersen et al., 2009). The tertiary structure was homology modeled by SWISSMODEL (http://swissmodel.expasy.org; Guex and Peitsch, 1997) on the basis of the available crystal structure of the C-type lectin DC-SIGNR (deposited in the protein data bank (PDB) code 1sl6c) and then visualized with PyMOL 1.2r1 (Schrödinger, LLC, New York, NY, USA).

\section{Mermaid isoforms expression and purification}

Recombinant His-Mermaid-3 corresponds to the previously published His-Mermaid, and was expressed and purified exactly as described (Bulgheresi et al., 2006). PCR fragments corresponding to amino acids 20-161 of (Sm-) Mermaid-1 and -2 were NdeI/ BamHI cloned into pET15b (Novagen, Merck, Darmstadt, Germany). The resulting His-Mermaid-1 and -2 fusion proteins contained an $\mathrm{N}$-terminal hexahistidine tag (His-tag) and were expressed in the E. coli strain BL21-AI (Invitrogen) according to the manufacturer's instructions. Bacterial lysates containing His-Mermaid-1, -2 and -3 were individually applied to nickel-chelated resins ( $1 \mathrm{ml}$ HisTrap chelating HP, Amersham Biosciences, charged with $50 \mathrm{mM} \mathrm{NiSO}{ }_{4}$ ) in binding buffer (8 $\mathrm{M}$ urea, $20 \mathrm{mM}$ $\mathrm{Na}_{2} \mathrm{HPO}_{4} / \mathrm{NaH}_{2} \mathrm{PO}_{4}, 0.5 \mathrm{M} \mathrm{NaCl}, 10 \mathrm{mM}$ imidazole) and were eluted with the same buffer (except for the imidazole concentration, which was increased to $0.5 \mathrm{M}$ ). Eluted proteins were dialysed against phosphate-buffered saline-containing decreasing urea concentrations to allow renaturation.

\section{Agglutination assays}

Bacterial pellets obtained as described above were re-suspended in filter-sterilized seawater to a final density corresponding to $\mathrm{OD} 600=1$. His-Mermaid-1, -2 and -3 were each added to 
separate $50 \mu \mathrm{l}$ aliquots of L. oneistus and S. majum symbionts (starting with a concentration of $10 \mu \mathrm{g} \mathrm{ml}^{-1}$, and using a dilution series to determine the minimum concentration sufficient to induce visible aggregation). Agglutination was carried out in $1.5 \mathrm{ml}$ tubes for $3 \mathrm{~h}$ at room temperature. For each symbiont and each Mermaid isoform, agglutination was performed in triplicate. Agglutinated and control symbionts were mounted onto glass slides for photographic documentation. For each treatment and the control, the size of the particles appearing in three randomly photographed microscopic fields were measured using ImageJ (National Institutes of Health, Bethesda, MD, USA), and compared the particle size distribution by rank-based KruskalWallis analysis of variance followed by Dunn's test for differences among groups. $P<0.01$ was considered to be statistically significant.

\section{Dissociation assays}

Dissociation assays were conducted as described (Bulgheresi et al., 2006). In brief, nine batches of 50 L. oneistus individuals were collected and each batch was immediately added to a tube containing $300 \mu \mathrm{l}$ filter-sterilized seawater. Each His-Mermaid isoform was added to three worm batches (of 50 individuals each, for a total of 150 worms per Mermaid isoform) to a make a final concentration of
$10 \mu \mathrm{g} \mathrm{ml} \mathrm{m}^{-1}$. Dissociation assays were carried out for $24 \mathrm{~h}$ at room temperature under gentle agitation. Worms were transferred to petridishes for photographic documentation after $<1 \mathrm{~h}, 2 \mathrm{~h}, 5 \mathrm{~h}, 9 \mathrm{~h}, 20 \mathrm{~h}$ and $24 \mathrm{~h}$.

\section{Results}

S. majum symbionts are phylogenetically distinct from L. oneistus symbionts

Direct sequencing of a $16 \mathrm{~S}$ rRNA gene fragment of the L. oneistus symbiont provided a single unambiguous sequence (Polz et al., 1994). Therefore, in this study we only constructed $16 \mathrm{~S}$ rRNA gene libraries from $S$. majum individuals. Comparison of the 1,499 nt-long 16S rRNA gene sequences of randomly picked clones obtained from three individuals showed that they consistently differed at a singlenucleotide position (sequence identity among them $>99.9 \%$ ). Therefore, we used only one $S$. majumderived 16S rRNA gene sequence (clone \#3-5) for phylogenetic analysis (HM776017). The tree displayed in Figure 1 shows that: (1) the obtained $16 \mathrm{~S}$ rRNA gene sequence is most closely related to three sequences (FM955329-FM955331) that originated from bacteria associated to an unknown Stilbonema species; (2) S. majum and L. oneistus symbionts are phylogenetically distinct $(97 \%$ sequence identity) and (3) they form a highly

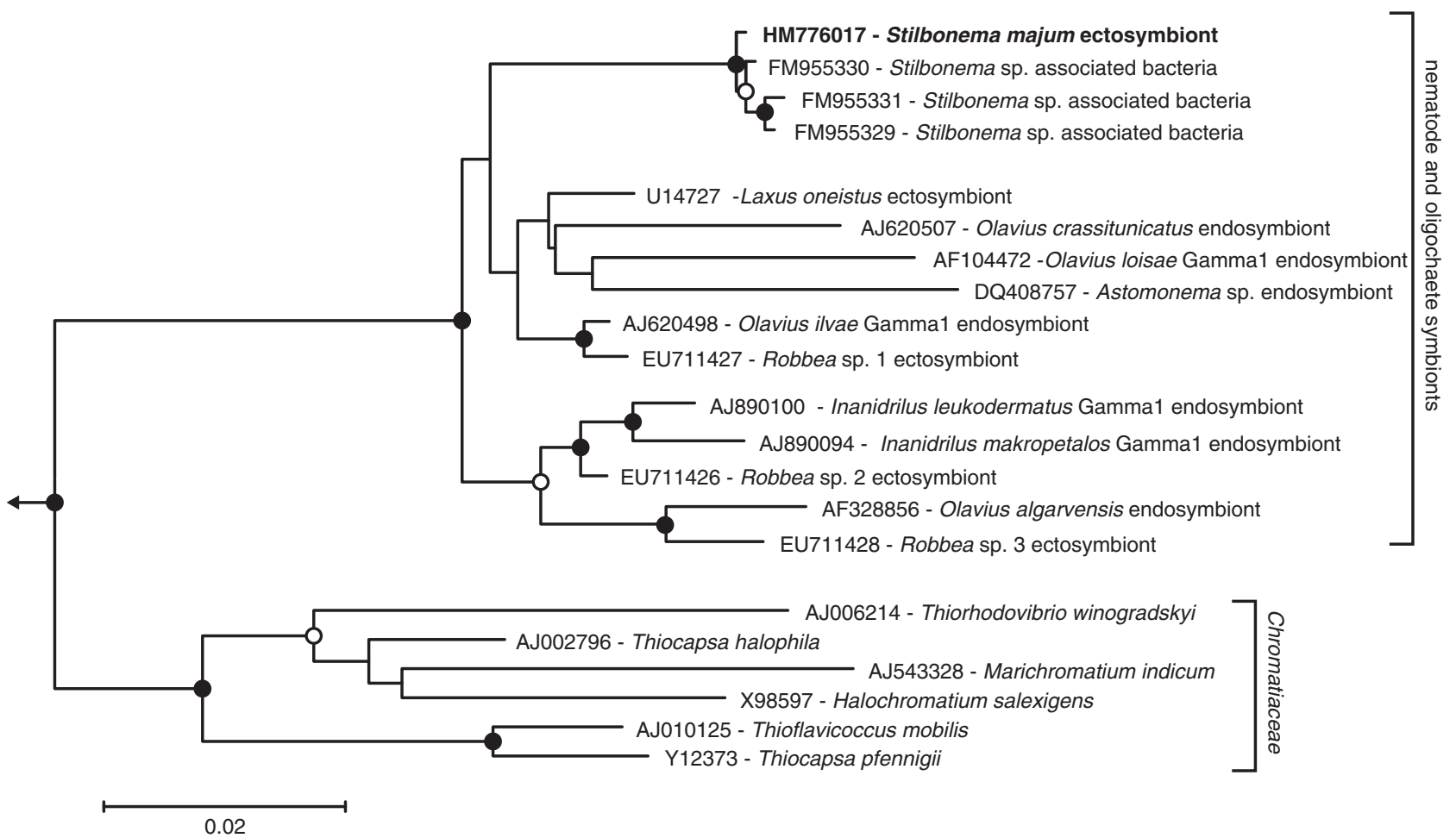

Figure 1 16S rRNA gene tree based on the most likely RAxML tree (GTR + I + G model of substitution). Filled and open circles indicate nodes supported by all four or at least two reconstruction methods, respectively (bootstrapping support $\geqslant 0.75$, posterior probabilities $\geqslant 0.9$ ). The arrow points to the out-group. Scale bar represents $2 \%$ estimated sequence divergence. GenBank accession numbers precede the names of the bacteria. 

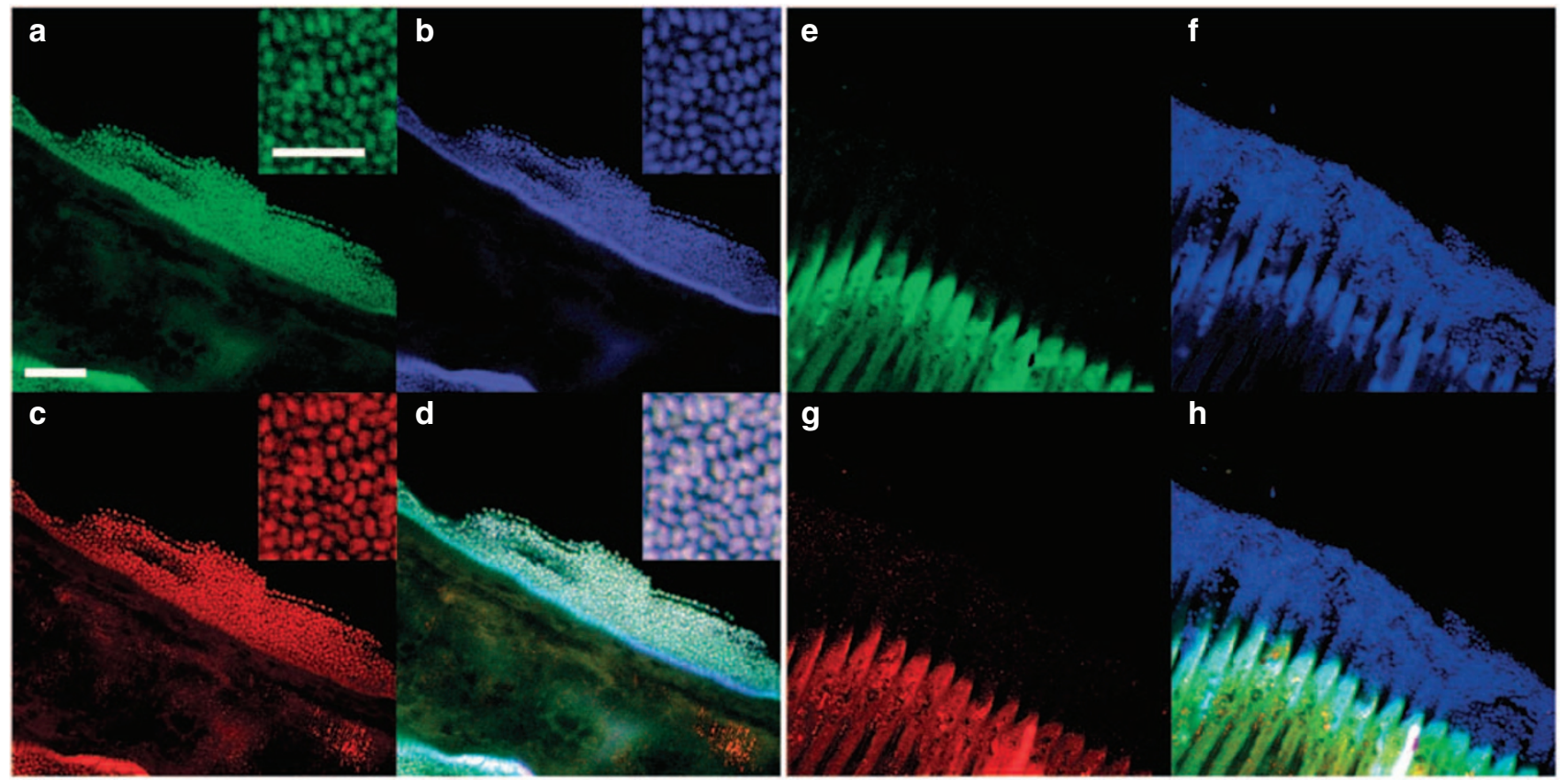

Figure 2 FISH LSCM of symbionts attached to the surface of a S. majum worm. Each symbiont is triple stained with specific probes targeting eubacteria (a), Gammaproteobacteria (b) and the $S$. majum symbiont (c). All symbionts are stained with a Gammaproteobacteriaspecific probe (f) but not with a nonsense control probe (e) or a Betaproteobacteria-specific probe (g). Panels (d) and (h) are overlay pictures of a-c and $\mathbf{e}-\mathbf{g}$, respectively. Scale bar is $6 \mu \mathrm{m}$ in $\mathbf{a}-\mathbf{h}$ and $3 \mu \mathrm{m}$ in the inserts.

supported phylogenetic group (all algorithms bootstrap support and posterior probability $\geqslant 0.99$ ) together with the sulfur-oxidizing symbionts of other thiotrophic nematodes (Robbea sp. and Astomonema sp.) and of marine gutless oligochaetes (Inanidrilus and Olavius spp.); and (4) this nematode-oligochaete symbiont cluster is most closely related to free-living sulfur-oxidizing Gammaproteobacteria from the family Chromatiaceae (Dubilier et al., 2008).

To confirm that the Gammaproteobacterial $16 \mathrm{~S}$ rRNA gene sequences derived from the $S$. majum symbionts, we carried out FISH with the symbiontspecific probe Sms444 (refer to Table 1 for detailed description of all the FISH probes used in this study). The bacteria attached to the worms were triple stained by this specific probe, as well as by the bacterial probe EUB338, and by the Gammaproteobacteria-specific probe GAM42a (Figure 2). In contrast, no FISH signal was detectable with the control probe NON338 or with a Betaproteobacteriaspecific probe, which differs from GAM42a at a single-nucleotide position (Figure 2). Moreover, use of the non-fluorescent competitor Rhs444 did not decrease the hybridization signal of the $S$. majum symbiont-specific probe (Supplementary Figure 1). FISH indicates that the bacteria covering $S$. majum belong to a single phylotype. This is consistent with our highly homogeneous 165 rRNA gene library, and with the scanning electron microscopy analysis showing only one bacterial morphotype covering this nematode species (Ott et al., 2004a,b).
L. oneistus and S. majum express different repertoires of Mermaid isoforms

To assess the degree of variation in the primary structure of the lectin CRD, we screened Mermaid cDNA libraries obtained from $L$. oneistus and $S$. majum to saturation. In the case of L. oneistus, besides Lo-Mermaid-1 and -2, we discovered nine isoforms bearing novel CRDs. As for S. majum, we identified 10 isoforms bearing novel CRDs, besides the three already known (Sm-Mermaid-1, -2 and -3). Figure 3 displays an alignment of all unique CRDs. For each species, new isoforms were numbered according to the order in which they were discovered. At least two cDNA clones encoded for each of them, which allows us to exclude sequencing mistakes as a source of variability. The amino acid substitution sites were conserved and occurred non-randomly in the 119 amino acid long CRD (12 and 15 variable positions in L. oneistus and $S$. majum, respectively). None of them directly affected the conserved amino acids, including those involved in calcium- or sugar-binding (black circles and arrowheads in Figure 3). Substitutions of hydrophilic with hydrophobic amino acids and vice versa (defined as non-conservative and underlined in Figure 3) never occurred in the helical structures or $\beta$-sheets. This also holds true for substitutions at positions 105, 108 and 109. These, however, occurred in the long-loop region, close to a core of amino acids always involved in sugar binding (black arrowheads in Figure 3). The additional amino acids participating in ligand-binding can 


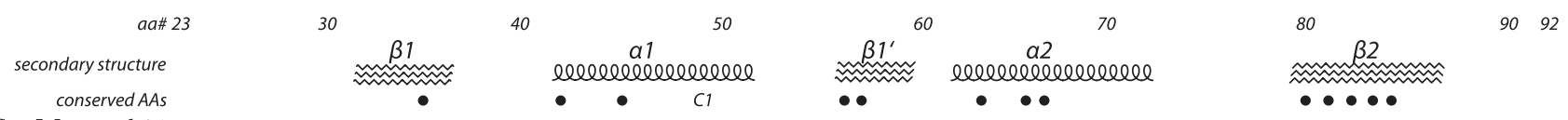

Sm Mermaid 01 GWLRSPQGTVVKLYRRSLSWSKADEFCKDVDGRLVVDRTADMHLFLIKNVLKEKKSRVWVGLRRTAPHSR

Sm Mermaid

Sm Mermaid 03

Sm Mermaid 04

Sm Mermaid 05

Sm Mermaid 06

Sm Mermaid 07

Sm Mermaid 08

Sm Mermaid 09

Sm Mermaid 10

Sm Mermaid 11

Sm Mermaid 12

Sm Mermaid 13

Lo Mermaid 01 GWLRSPQGTVVKLYRRSLSWSKADEFCKDVDGRLVVDRTADMHLFLIKNVLKEKKSRVWVGLRRTAPHSR Lo Mermaid 02

Lo Mermaid 03

Lo Mermaid 04

Lo Mermaid 05

Lo Mermaid 06

Lo Mermaid 07

Lo Mermaid 08

Lo Mermaid 09

Lo Mermaid 10

Lo Mermaid 11
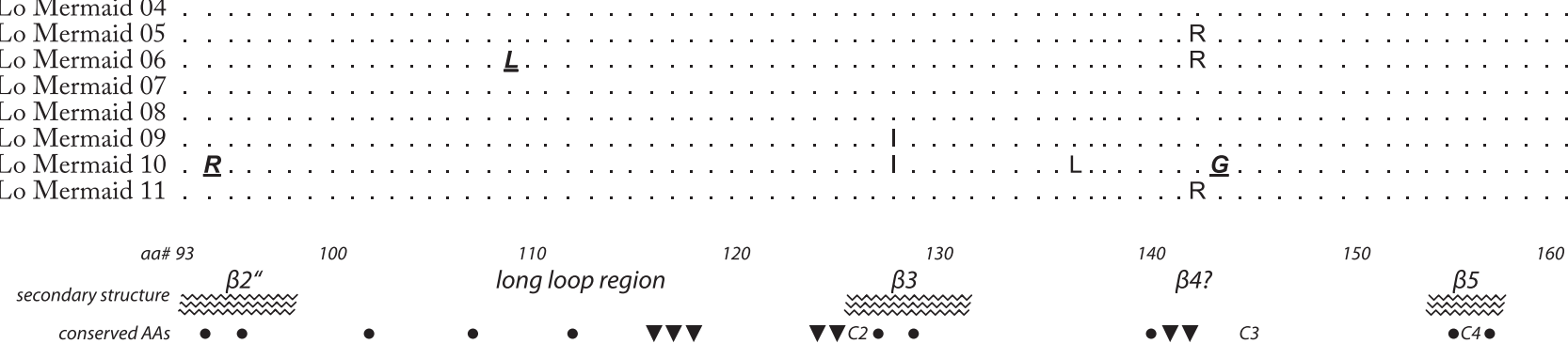

Sm Mermaid 01TWIWSDGTRQNEDDLDANLWLRDEPNDAAGEEECALFMYSPWEKAWGLNDYLCRGGCRNYQFICEKWIR Sm Mermaid 02

Sm Mermaid 03

Sm Mermaid 04

Sm Mermaid 05

Sm Mermaid 06

Sm Mermaid 07

Sm Mermaid 08

Sm Mermaid 09

Sm Mermaid 10

Sm Mermaid 11

Sm Mermaid 12

Sm Mermaid 13

Lo Mermaid 02

Lo Mermaid 03

Lo Mermaid 04

Lo Mermaid 05

Lo Mermaid 06

Lo Mermaid 07

Lo Mermaid 08

Lo Mermaid 09

Lo Mermaid 10

Lo Mermaid 11

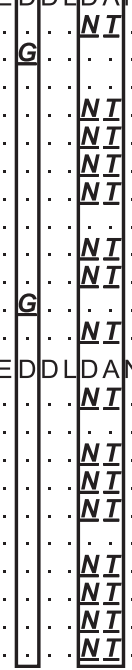

Figure 3 Protein sequence alignment of the CRDs of L. oneistus (Lo) and S. majum (Sm) Mermaid isoforms. Amino acid (aa) numbering, NetSurfP-predicted secondary structures (helices and $\beta$-sheets), and conserved aas symbols overlie the alignments and were selected and named according to Zelensky \& Gready (2003): C1-C4 are the four Cysteines implicated in the formation of two disulfide bridges; black arrowheads mark conserved aas for sugar- and calcium-binding; black circles mark other structurally important conserved aas. Dots represent aas identical to isoform 1. Non-conservative aa substitutions (see text for a definition) are in italics and underlined. Nonconserved aa substitutions occurring in the vicinity of the ligand-binding region (105, 108 and 109) are boxed. GenBank accession numbers of Sm-Mermaid-4 to -13 are HM804996-HM805005; GenBank accession numbers of Lo-Mermaid-3 to -11 are HM805006HM805014.

only be determined for a given sugar and only with a yet unavailable crystal structure. Nevertheless, in the DC-SIGNR-based tertiary structure predictions (Figure 4), positions 105, 108 and 109 are in a protein fold that is easily accessible and close to the conserved sugar-binding amino acids, and may therefore participate in sugar-binding (Feinberg et al., 2001).

By considering only these three amino acid positions, we classified all $L$. oneistus and $S$. majum CRDs into three types. The isoforms bearing the DDA-type CRD display amino acids Asp, Asp and Ala at these positions, those belonging to the DNT-type display Asp, Asn and Thr, and those belonging to the GDA-type display Gly, Asp and Ala. In the case of L. oneistus, $63 \%$ of the cDNA clones encoded for DNT-type CRDs and $37 \%$ for DDA-type CRDs. In the case of $S$. majum, $52 \%$ encoded for DNT-type CRDs, 34\% for DDA type and $14 \%$ for GDA type. Notably, no L. oneistus cDNA encoded for a GDA-type CRD. 
a

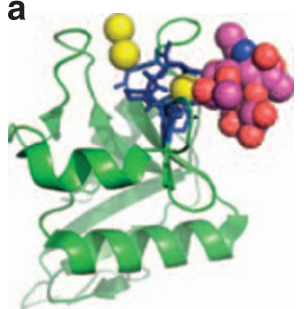

b

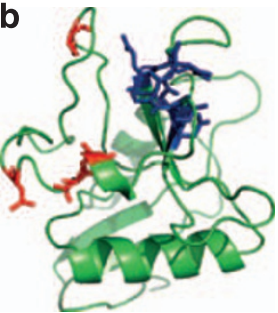

C

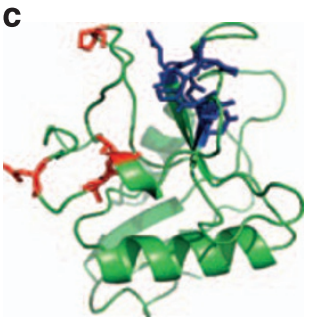

Figure 4 Three-dimensional model of the CRDs of DC-SIGNR (a) and Mermaid isoforms 1, 2 and 3 (b, c and d, respectively). All PyMOL renderings are based on the resolved structure of DC-SIGNR 1SL6. (a-d) conserved ligand-binding sites (as in Figure 3) are shown in blue, variable positions are shown in red. (a) Calcium atoms are indicated as yellow spheres and carbohydrate ligand (Lewis X) by a ball molecular model.

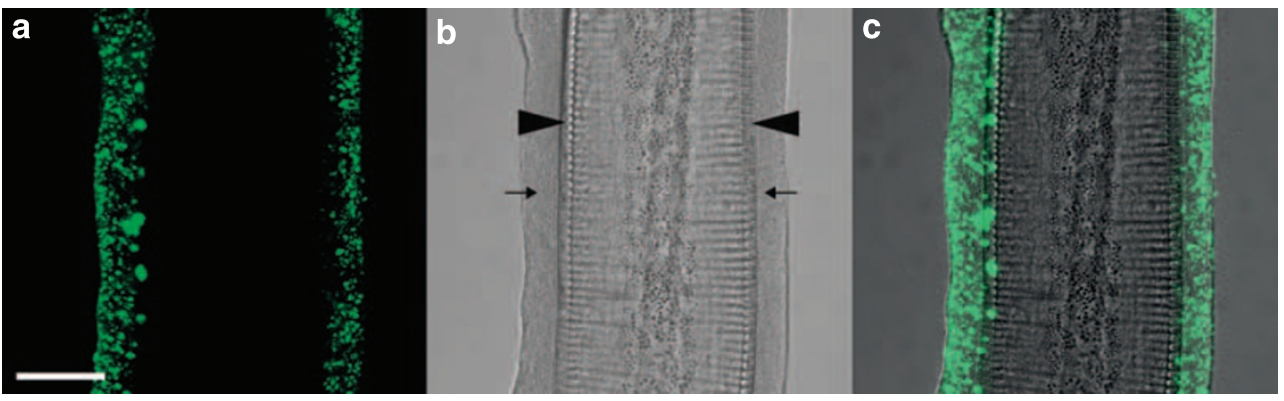

Figure 5 S. majum Mermaid localization pattern. LSCM picture of the bacterial coat of a $S$. majum nematode, immunostained with a specific anti-Mermaid antibody and Alexa488-conjugated secondary anti-rabbit antibody (a), corresponding differential contrast image (b) and overlay (c). Arrows point to the bacterial coat and arrowheads to the nematode cuticle. Scale bar is $20 \mu \mathrm{m}$.

To prove that $S$. majum expresses not only the mRNA but also the Mermaid protein, we immunostained it with a specific anti-Mermaid antibody. The pronounced staining of the bacterial coat indicates that the lectin is secreted by $S$. majum onto its cuticle (Figure 5). Immunostaining with rabbit pre-immune serum did not result in any significant staining (Supplementary Figure 2).

L. oneistus symbionts are most efficiently aggregated by Mermaid-2 and S. majum symbionts by Mermaid-3 To assess whether the three CRD types described above agglutinate $L$. oneistus and $S$. majum symbionts with different efficiency, we expressed recombinant forms of three isoforms, His-Mermaid-1, -2 and -3 , bearing CRD types DDA, DNT and GDA, respectively; His-Mermaid-3 corresponds to the recombinant form His-Mermaid produced and analyzed in Bulgheresi et al. (2006). As shown in Figure 6, His-Mermaid-2 induced the largest aggregates of L. oneistus symbionts, whereas His-Mermaid-3 incubation resulted in the largest $S$. majum symbiont aggregates. His-Mermaid-1-induced aggregates were comparable to those obtained with His-Mermaid-2 in both L. oneistus and S. majum symbionts. Moreover, dilution series showed that the minimum concentration sufficient to induce visible aggregation varied significantly among different Mermaid isoforms. Only $1 \mu \mathrm{g} \mathrm{ml}^{-1}$ of His-Mermaid-2 or -1 , but $10 \mu \mathrm{g} \mathrm{ml}^{-1}$ of His-Mermaid-3 that is, a 10-fold higher concentration, is necessary to induce L. oneistus symbiont aggregation. As for $S$. majum symbionts, a $5 \mu \mathrm{g} \mathrm{ml}^{-1}$ concentration of His-Mermaid-3 was sufficient to aggregate them (data not shown).

Taken together, our data show that the three tested isoforms, bearing three distinct CRDs, agglutinate $L$. oneistus and $S$. majum symbionts with different efficiency. In particular, we expect the DNT type (Mermaid-2) to have a central role in L. oneistus symbiont aggregation, and the GDA type (Mermaid-3) to predominantly mediate $S$. majum symbiont aggregation. Therefore, expression of different isoform repertoires, or of the same isoforms at different concentrations, can underlie the attachment of different symbionts to the two co-occurring nematodes.

Incubation of L. oneistus in His-Mermaid-2 leads to complete symbiont detachment

In a previous report, we showed that incubation of live L. oneistus in recombinant His-Mermaid-3 resulted in significant symbiont detachment from all treated nematodes (Bulgheresi et al., 2006). This effect was attributed to competition of the recombinant lectin with the native one. Nonetheless, symbiont patches persisted on the surface of lectin-incubated nematodes, leading to the speculation that other lectins, or other lectin isoforms, might be needed to achieve complete symbiont detachment.

We tested whether His-Mermaid-1 or -2, both displaying higher affinity for $L$. oneistus symbionts than His-Mermaid-3 in agglutination experiments, can cause complete host-symbiont dissociation. 

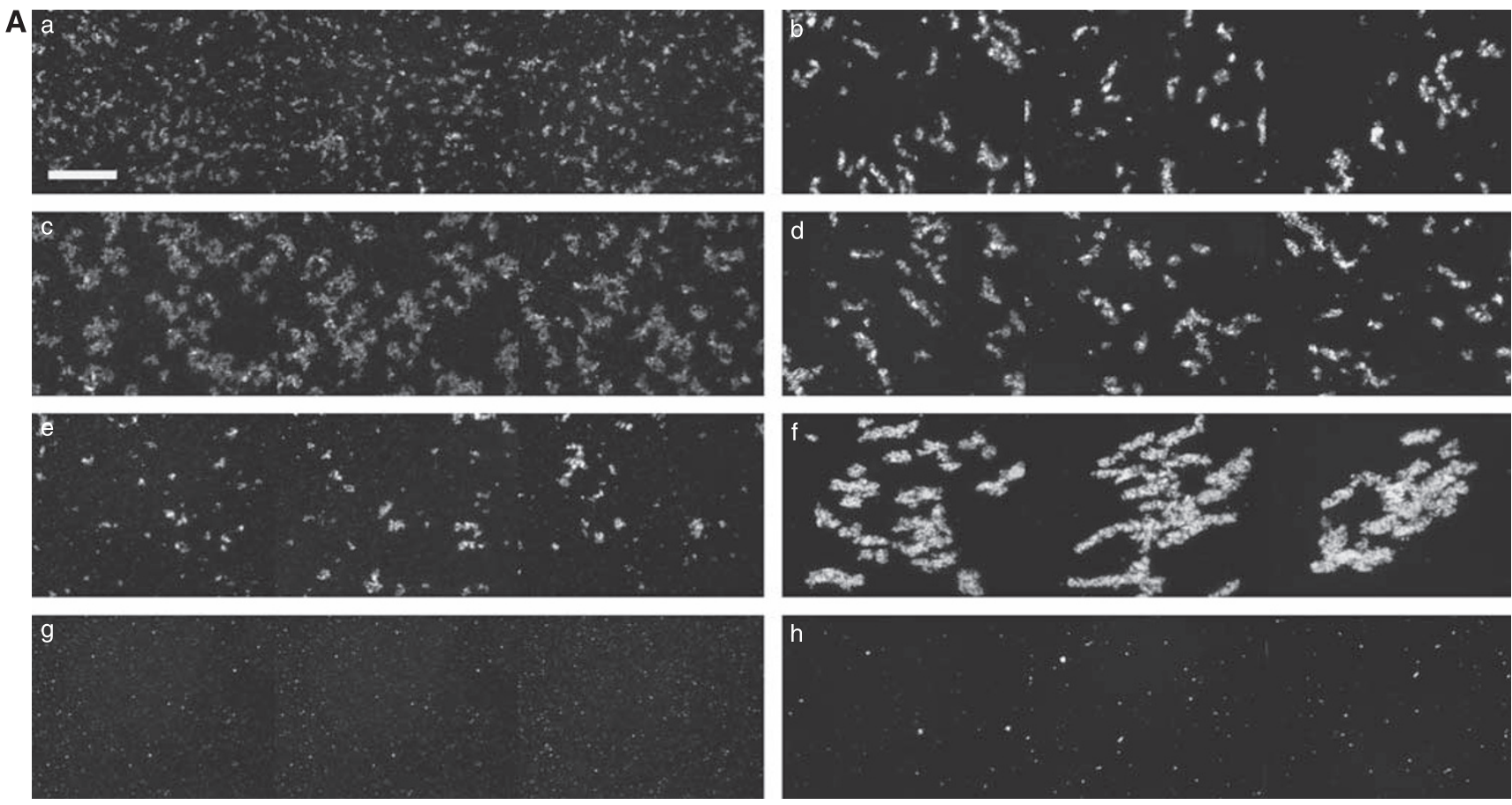

B

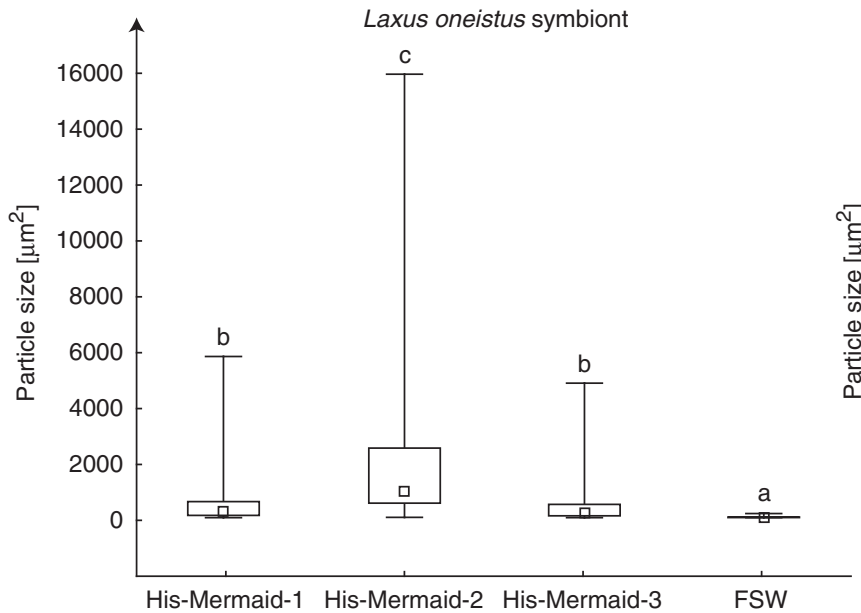

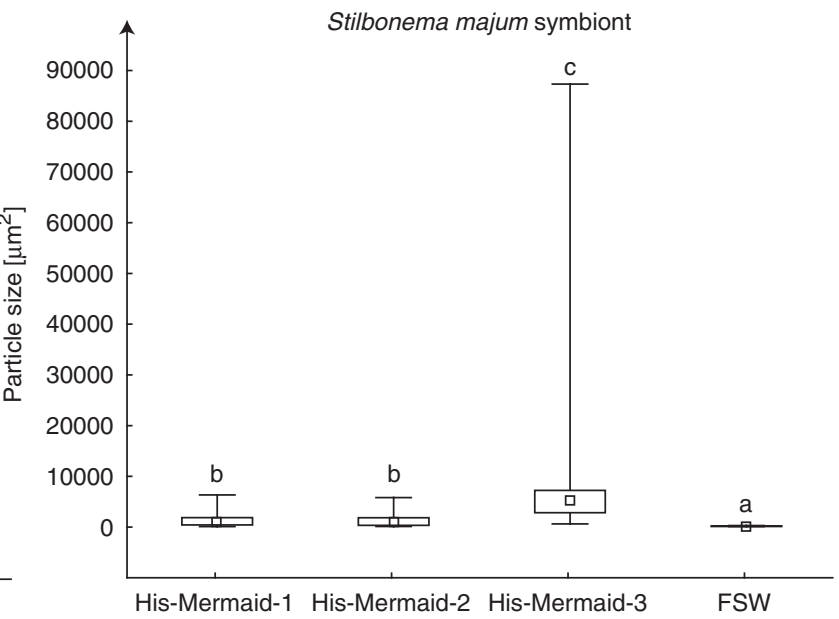

Figure 6 Agglutination assays. (A). Light microscope images of L. oneistus and $S$. majum symbionts incubated in $10 \mu \mathrm{ml} \mathrm{l}^{-1}$ His-Mermaid-1 (a and b), His-Mermaid-2 (c and d), His-Mermaid-3 (e and f) and no lectin (g and h). Each panel was obtained by merging the photographs of three randomly chosen microscopic fields. Scale bar is $200 \mu \mathrm{m}$. (B) Box plot of particles size of L. oneistus (left plot) and $S$. majum symbionts (right plot) incubated in $10 \mu \mathrm{g} \mathrm{ml}^{-1}$ His-Mermaid-1, His-Mermaid-2, His-Mermaid-3 and lectin-free filtered seawater as control. The bars indicate maximum and minimum, the boxes indicate the $25-75 \%$ quartiles and the squares indicate the median of the particle size distribution. Different letters above the graphs indicate statistically different (Dunn's post-hoc P<0.01) particle size distributions of the treatments for each of the symbionts. For details on the $P$-values see Supplementary Table 1.

Figure 7 shows that L. oneistus individuals incubated in His-Mermaid-2 (b) started to lose the bacteria earlier than those incubated in His-Mermaid-1 or -3 (a and c, respectively). Moreover, after $20 \mathrm{~h}$ incubation in His-Mermaid-1 or -2 , the nematodes completely lost their bacterial coat (e, f, i and j), whereas, as previously reported (Bulgheresi et al., 2006), symbiont patches are still visible on His-Mermaid-3-incubated nematodes (g and k).

The ability of the three isoforms to cause different degrees of host-symbiont dissociation confirms what we observed in the agglutination experiments: the three isoforms are functionally different, for example, they aggregate $L$. oneistus symbionts with different efficiency. Moreover, we expect the DNTtype CRD (Mermaid-2) to have a predominant role in $L$. oneistus symbiont attachment.

\section{Discussion}

Several stilbonematid species have been reported to establish monospecific ectosymbioses. The cuticles of L. oneistus (Polz et al., 1994) and of three Robbea species (Bayer et al., 2009) are each covered by one 

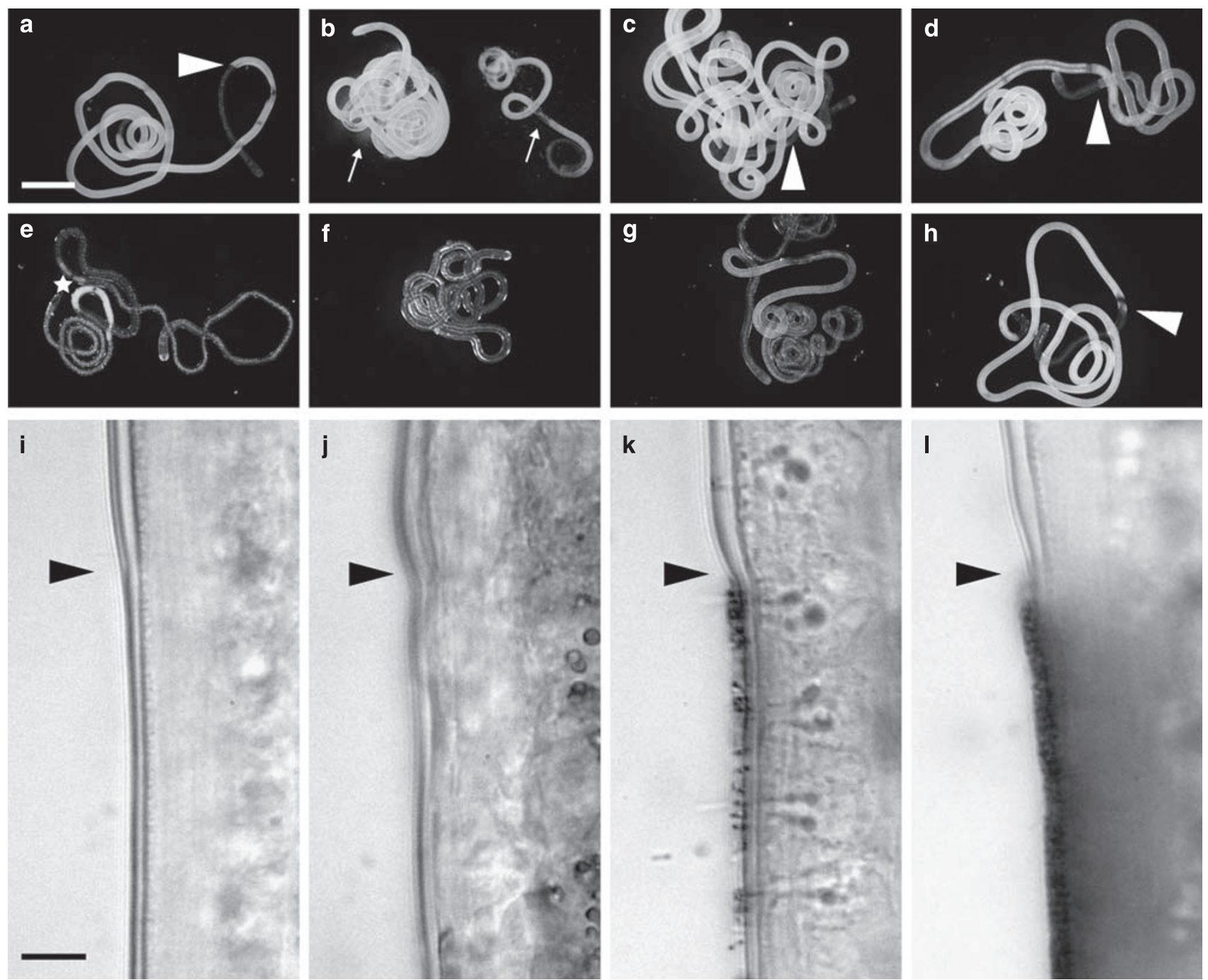

Figure 7 Dissociation assays. Light microscope images of L. oneistus individuals incubated in $10 \mu g \mathrm{ml}^{-1} \mathrm{His}^{-\mathrm{Mermaid}-1}$ (a, e and i), His-Mermaid-2 (b, f and j), His-Mermaid-3 (c, g and $\mathbf{k}$ ) and no lectin (d, $\mathbf{h}$ and $\mathbf{l})$. Nematodes were photographed after $<1 \mathrm{~h}(\mathbf{a}-\mathbf{d})$ and $20 \mathrm{~h}$ $(\mathbf{e}-\mathbf{l})$ incubation. White and black arrowheads point to the beginning of the bacterial coat. White arrows in (b) point to a nematode region where symbiont are detaching (left) and already detached (right). Two eggs inside the nematode (star) are visible after symbiont detachment. Scale bar is $200 \mu \mathrm{m}$ in $\mathbf{a}-\mathbf{h}$ and $20 \mu \mathrm{m}$ in $\mathbf{i}-\mathbf{l}$.

phylotype of Gammaproteobacteria, each displaying a certain morphotype and spatial arrangement on the host. The present work adds $S$. majum to those hosts able to engage in a binary association. This high degree of specificity has so far been reported for only two other bacterial ectosymbioses: the cave amphipod Niphargus ictus (Dattagupta et al., 2009) and the leaf-cutting ant Acromyrmex (Poulsen et al., 2005). The identification of the $S$. majum symbiont $16 \mathrm{~S}$ rRNA gene and its phylogenetic placement within the Gammaproteobacteria reiterates earlier findings: (1) stilbonematid symbionts tightly cluster with the sulfide-oxidizing endosymbionts of a marine nematode and of gutless marine oligochaetes (Musat et al., 2007) (Dubilier et al., 2008); (2) all the phylotypes contained in this cluster cannot be grouped according to the geographical origin of their hosts; and (3) their closest relatives are free living and not symbiotic. Given that stilbonematid and symbiont phylogenies do not match (Bayer et al., 2009), the partners probably did not cospeciate.

Protein-sugar interactions have a central role in host-symbiont attachment in virtually all microbial symbioses, including plant-rhizobia, ectomycorrhiza, cnidarian-zooxanthellae, lucinid mussels and the ones established by thiotrophic marine nematodes (Wood-Charlson et al., 2006; Gourdine and Smith-Ravin, 2007; Kvennefors et al., 2008; De Hoff et al., 2009; Bright and Bulgheresi, 2010; Chaston and Goodrich-Blair, 2010). Here, we showed that one to three amino acid replacements in a hostsecreted sugar-binding protein are sufficient to radically affect its ability to agglutinate two different symbiont phylotypes. More specifically, incubation of L. oneistus symbionts in a DNT-type CRD results in 
the largest bacterial aggregates, whereas a GDA type induces the largest $S$. majum symbiont aggregates. Therefore, acquisition of specific symbionts by two co-occurring stilbonematids might be mediated by minor differences in lectin protein sequence. This is the first report of lectin isoforms differing in their symbiont-binding capacity. cDNA analysis of a family of Acropora millepora mannosebinding proteins (Millectins; Kvennefors et al., 2008) revealed extensive sequence variation. As observed for the Mermaids, some substitutions occur in the vicinity of the ligand-binding region. Kvennefors et al. (2008) speculated that amino acidic variability would enable the coral-secreted Millectins to recognize a variety of symbionts and pathogens.

Agglutination and dissociation assays indicate that the three CRD types differ in their symbiont-binding activity. This might be because of their different polymerization capacities or sugar specificities. Detailed analysis of the latter, as well as of the lipopolysaccharide composition of the two symbiont phylotypes, promise to disclose the effects of the three analyzed amino acid substitutions on Mermaid activity. It is possible that the specificity of the DNT-type CRD (displayed by Mermaid-2) matches the sugar composition of $L$. oneistus symbiont lipopolysaccharide and the specificity of the GDA-type CRD (displayed by Mermaid-3) that of the S. majum symbiont. Although we did not attempt to dissociate the latter from its host by incubation in different recombinant Mermaid isoforms, as $S$. majum does not tolerate long incubations outside the marine environment, agglutination tests suggest that GDA-type Mermaids are predominantly mediating symbiont attachment to this stilbonematid species.

The Mermaids are not the first molecules to vary between phylogenetically related hosts, thereby affecting symbiosis specificity. Other very wellknown examples are the plant flavonoids and, on the symbiont side, the rhizobial Nod factors (Cooper, 2007). This study does not exclude that other host (C-type) lectins might participate in symbiont discrimination. Additionally, the presence of another given gene (symbiosis specificity mechanism (b), see introduction) could be involved. Examples of genes that can specify the host range are the nematode intestine localization (nil) $B$ and $C$ genes of insect-killing nematode symbionts (Cowles and Goodrich-Blair, 2008) and the regulator of symbiotic colonization sensor $(\mathrm{rscS})$ gene of squid symbionts (Mandel et al., 2009).

A high rate of amino acid substitutions is a hallmark of positive selection. This is defined as an excess in the non-synonymous nucleotide substitution rate $(\mathrm{dN})$ relative to the synonymous rate $(\mathrm{dS})$ when compared with neutral expectations (Hughes and Nei, 1988). Positive selection acts on a multigenes family and favours diversity at the amino acid level. Evidence of positive selection has been reported for many immunity genes
(Hughes, 1994; Tiffin and Moeller, 2006; Hayes et al., 2010). Molecular population genetics studies are needed to find out whether the Mermaids are evolving adaptively under diversifying, selective pressure exerted by the symbionts. Moreover, quantitative PCR and/or isoform-specific antibodies are required to define the relative abundance of each isoform transcript/protein in each stilbonematid species.

The finding that different Mermaid isoforms can discriminate different symbionts is a true step forward in understanding the mechanisms of symbiosis specificity. So far, only pathogenassociated molecular pattern receptors were known to be tailored in such a custom-made manner. New research avenues will be to investigate whether the different Mermaid CRDs display different affinity for pathogens such as the human immunodeficiency virus-1 (HIV-1) and their role in stilbonematid innate immunity defense.

\section{Acknowledgements}

We are very grateful to Anja Spang for her insightful comments on the manuscript. This work was supported by the Austrian Research Promotion Agency (FFG) project 814324 (SB and NRH) and by the Austrian Science Fund (FWF) project 20394 (JAO, HG and UD).

\section{References}

Alm EW, Oerther DB, Larsen N, Stahl DA, Raskin L. (1996). The oligonucleotide probe database. Appl Environ Microbiol 62: 3557-3559.

Altschul SF, Gish W, Miller W, Myers EW, Lipman DJ. (1990). Basic local alignment search tool. J Mol Biol 215: 403-410.

Amann RI, Krumholz L, Stahl DA. (1990). Fluorescentoligonucleotide probing of whole cells for determinative, phylogenetic, and environmental studies in microbiology. J Bacteriol 172: 762-770.

Bayer C, Heindl NR, Rinke C, Lücker S, Ott JA, Bulgheresi S. (2009). Molecular characterization of the symbionts associated with marine nematodes of the genus Robbea. Environ Microbiol Rep 1: 136-144.

Bright M, Bulgheresi S. (2010). A complex journey: transmission of microbial symbionts. Nat Rev Microbiol 8: 218-230.

Brosius J, Dull TJ, Sleeter DD, Noller HF. (1981). Gene organization and primary structure of a ribosomal RNA operon from Escherichia coli. J Mol Biol 148: 107-127.

Brosius J, Palmer ML, Kennedy PJ, Noller HF. (1978). Complete nucleotide sequence of a $16 \mathrm{~S}$ ribosomal RNA gene from Escherichia coli. Proc Natl Acad Sci USA 75: 4801-4805.

Bulgheresi S, Schabussova I, Chen T, Mullin NP, Maizels RM, Ott JA. (2006). A new C-type lectin similar to the human immunoreceptor DC-SIGN mediates symbiont acquisition by a marine nematode. Appl Environ Microbiol 72: 2950-2956. 
Chaston J, Goodrich-Blair H. (2010). Common trends in mutualism revealed by model associations between invertebrates and bacteria. FEMS Microbiol Rev 34: 41-58.

Cooper JE. (2007). Early interactions between legumes and rhizobia: disclosing complexity in a molecular dialogue. J Appl Microbiol 103: 1355-1365.

Cowles CE, Goodrich-Blair H. (2008). The Xenorhabdus nematophila nilABC genes confer the ability of Xenorhabdus spp. to colonize Steinernema carpocapsae nematodes. J Bacteriol 190: 4121-4128.

Dattagupta S, Schaperdoth I, Montanari A, Mariani S, Kita N, Valley JW et al. (2009). A novel symbiosis between chemoautotrophic bacteria and a freshwater cave amphipod. ISME J 3: 935-943.

De Hoff P, Brill L, Hirsch A. (2009). Plant lectins: the ties that bind in root symbiosis and plant defense. Mol Genet Genomics 282: 1-15.

Drummond A, Ashton B, Cheung M, Heled J, Kearse M, Moir $\mathrm{R}$ et al. (2009). Geneious v4.7 available fromhttp://www.geneious.com/.

Dubilier N, Bergin C, Lott C. (2008). Symbiotic diversity in marine animals: the art of harnessing chemosynthesis. Nat Rev Microbiol 6: 725-740.

Feinberg H, Mitchell DA, Drickamer K, Weis WI. (2001). Structural basis for selective recognition of oligosaccharides by DC-SIGN and DC-SIGNR. Science 294: 2163-2166.

Gourdine JP, Smith-Ravin EJ. (2007). Analysis of a cDNAderived sequence of a novel mannose-binding lectin, codakine, from the tropical clam Codakia orbicularis. Fish Shellfish Immunol 22: 498-509.

Guex N, Peitsch M. (1997). SWISS-MODEL and the Swiss-Pdbviewer: an environment for comparative protein modeling. Electrophoresis 18: 2714-2723.

Hayes M, Eytan R, Hellberg M. (2010). High amino acid diversity and positive selection at a putative coral immunity gene (tachylectin-2). BMC Evol Biol 10: 150.

Hentschel U, Berger EC, Bright M, Felbeck H, Ott JA. (1999). Metabolism of nitrogen and sulfur in ectosymbiotic bacteria of marine nematodes (Nematoda, Stilbonematinae). Mar Ecol Prog Ser 183: 149-158.

Hughes AL. (1994). The evolution of functionally novel proteins after gene duplication. Proc Biol Sci 256: 119-124.

Hughes AL, Nei M. (1988). Pattern of nucleotide substitution at major histocompatibility complex class I loci reveals overdominant selection. Nature 335: 167-170.

Juretschko S, Timmermann G, Schmid M, Schleifer KH, Pommerening-Roser A, Koops HP et al. (1998). Combined molecular and conventional analyses of nitrifying bacterium diversity in activated sludge: Nitrosococcus mobilis and Nitrospira-like bacteria as dominant populations. Appl Environ Microbiol 64: 3042-3051.

Kane MD, Poulsen LK, Stahl DA. (1993). Monitoring the enrichment and isolation of sulfate-reducing bacteria by using oligonucleotide hybridization probes designed from environmentally derived 16S rRNA sequences. Appl Environ Microbiol 59: 682-686.

Katoh K, Kuma K-I, Toh H, Miyata T. (2005). MAFFT version 5: improvement in accuracy of multiple sequence alignment. Nucleic Acids Res 33: 511-518.

Kvennefors ECE, Leggat W, Hoegh-Guldberg O, Degnan BM, Barnes AC. (2008). An ancient and variable mannose-binding lectin from the coral Acropora millepora binds both pathogens and symbionts. Dev Comp Immunol 32: 1582-1592.

Loy A, Arnold R, Tischler P, Rattei T, Wagner M, Horn M. (2008). Probecheck-a central resource for evaluating oligonucleotide probe coverage and specificity. Environ Microbiol 10: 2894-2898.

Ludwig W, Strunk O, Westram R, Richter L, Meier H, Yadhukumar et al. (2004). ARB: a software environment for sequence data. Nucleic Acids Res 32: 1363-1371.

Mandel MJ, Wollenberg MS, Stabb EV, Visick KL, Ruby EG. (2009). A single regulatory gene is sufficient to alter bacterial host range. Nature 458: 215-218.

Manz W, Amann R, Ludwig W, Wagner M, Schleifer K-H. (1992). Phylogenetic oligodeoxynucleotide probes for the major subclasses of proteobacteria: problems and solutions. Syst Appl Microbiol 15: 593-600.

McMahon SA, Miller JL, Lawton JA, Kerkow DE, Hodes A, Marti-Renom MA et al. (2005). The C-type lectin fold as an evolutionary solution for massive sequence variation. Nat Struct Mol Biol 12: 886-892.

Mittal R, Bulgheresi S, Emami C, Prasadarao NV. (2009). Enterobacter sakazakii targets DC-SIGN to induce immunosuppressive responses in dendritic cells by modulating MAPKs. J Immunol 183: 6588-6599.

Musat N, Giere O, Gieseke A, Thiermann F, Amann R, Dubilier N. (2007). Molecular and morphological characterization of the association between bacterial endosymbionts and the marine nematode Astomonema sp. from the Bahamas. Environ Microbiol 9: 1345-1353.

Nabatov AA, de Jong MA, de Witte L, Bulgheresi S, Geijtenbeek TB. (2008). C-type lectin Mermaid inhibits dendritic cell mediated HIV-1 transmission to CD4+ T cells. Virology 378: 323-328.

Nebelsick M, Blumer M, Novak R, Ott JA. (1992). A new glandular sensory organ in Catanema sp. (Nematoda, Stilbonematinae). Zoomorphology 112: 17-26.

Nussbaumer AD, Bright M, Baranyi C, Beisser CJ, Ott JA. (2004). Attachment mechanism in a highly specific association between ectosymbiotic bacteria and marine nematodes. Aquat Microb Ecol 34: 239-246.

Ott JA, Bright M, Bulgheresi S. (2004a). Marine microbial thiotrophic ectosymbioses. Oceanogr Mar Biol Annu Rev 42: 95-118.

Ott JA, Bright M, Bulgheresi S. (2004b). Symbioses between marine nematodes and sulfur-oxidizing chemoautotrophic bacteria. Symbiosis 36: 103-126.

Ott JA, Novak R, Schiemer F, Hentschel U, Nebelsick M, Polz M. (1991). Tackling the sulfide gradient: a novel strategy involving marine nematodes and chemoautotrophic ectosymbionts. PSZN I: Mar Ecol 12: 261-279.

Petersen B, Petersen TN, Andersen P, Nielsen M, Lundegaard C. (2009). A generic method for assignment of reliability scores applied to solvent accessibility predictions. BMC Struct Biol 9: 51.

Peumans WJ, Van Damme E. (1995). Lectins as plant defense proteins. Plant Physiol 109: 347-352.

Polz MF, Distel DL, Zarda B, Amann R, Felbeck H, Ott JA et al. (1994). Phylogenetic analysis of a highly specific association between ectosymbiotic, sulfur-oxidizing bacteria and a marine nematode. Appl Environ Microbiol 60: 4461-4467.

Polz MF, Harbison C, Cavanaugh CM. (1999). Diversity and heterogeneity of epibiotic bacterial communities on the marine nematode Eubostrichus dianae. Appl Environ Microbiol 65: 4271-4275.

Poulsen M, Cafaro M, Boomsma JJ, Currie CR. (2005). Specificity of the mutualistic association between 
actinomycete bacteria and two sympatric species of Acromyrmex leaf-cutting ants. Mol Ecol 14: 3597-3604.

Pradillon F, Schmidt A, Peplies J, Dubilier N. (2007). Species identification of marine invertebrate early stages by whole-larvae in situ hybridisation of $18 \mathrm{~S}$ ribosomal RNA. Mar Ecol Prog Ser 333: 103-116.

Ronquist F, Huelsenbeck JP. (2003). MrBayes 3: bayesian phylogenetic inference under mixed models. Bioinformatics 19: 1572-1574.

Schizas NV, Street GT, Coull BC, Chandler GT, Quattro JM. (1997). An efficient DNA extraction method for small metazoans. Mol Mar Biol Biotechnol 6: 381-383.

Stamatakis A. (2006). RAxML-VI-HPC: maximum likelihood-based phylogenetic analyses with thousands of taxa and mixed models. Bioinformatics 22: 2688-2690.

Tiffin P, Moeller DA. (2006). Molecular evolution of plant immune system genes. Trends Genet 22: 662-670.

Wallner G, Amann R, Beisker W. (1993). Optimizing fluorescent in situ hybridization with rRNA-targeted oligonucleotide probes for flow cytometric identification of microorganisms. Cytometry 14: 136-143.

Wood-Charlson EM, Hollingsworth LL, Krupp DA, Weis VM. (2006). Lectin/glycan interactions play a role in recognition in a coral/dinoflagellate symbiosis. Cell Microbiol 8: $1985-1993$.

Zelensky AN, Gready JE. (2003). Comparative analysis of structural properties of the C-type-lectin-like domain (CTLD). Proteins 52: 466-477.

Zhang P, Skurnik M, Zhang SS, Schwartz O, Kalyanasundaram R, Bulgheresi S et al. (2008). Human dendritic cell-specific intercellular adhesion molecule-grabbing nonintegrin (CD209) is a receptor for Yersinia pestis that promotes phagocytosis by dendritic cells. Infect Immun 76: 2070-2079.

Zhang P, Snyder S, Feng P, Azadi P, Zhang S, Bulgheresi S et al. (2006). Role of $\mathrm{N}$-acetylglucosamine within core lipopolysaccharide of several species of gram-negative bacteria in targeting the DC-SIGN (CD209). J Immunol 177: 4002-4011.

Supplementary Information accompanies the paper on The ISME Journal website (http://www.nature.com/ismej) 